\title{
African Pragmatic Spiritualism as Neo-Science: A Bergsonian/Whiteheadian Critique of Hountondji
}

\author{
Anthony Afe. Asekhauno ${ }^{1}$, Emmanuel Asia ${ }^{2}$ \\ ${ }^{1,2}$ Department of Philosophy, University of Benin, Nigeria \\ anthony.aaasekhauno@gmail.com,emmanuel.asia@uniben.edu
}

\begin{abstract}
Arguably, spiritualism is the most central of African philosophical systems. Amongst Africans, all reality is replete with spiritual involvement a pragmatic involvement. Spiritualism is typical and topical all around traditional African cultures, empirically manifested in all areas of human knowledge and experience including medicine, communication and transportation, entertainment, and the disquisition of justice. African spiritual capacity is a pragmatic reflection of African didactic strides. While this categorization may be apt and adequate for those sympathetic with truth and the African course, it, however, is either untrue or unscientific, a mark of primitivism. Clearly, it is outmoded and untenable to some others, including the Ivoirian-born Beninese Paulin Hountondji. This work reviews the major substance of Hountondji's critical views on African spiritualism with a view to debunking them by adducing by the canons set by the process philosophies of Henry Bergson and Alfred North Whitehead. The trajectory attempts to build a theoretical pedestal for the grounding of an African esoteric philosophy, which is at once uniquely spiritual and pragmatic-hence the phrase, pragmatic spiritualism or spiritual pragmatism; a method and model recommended for wider feat in all human affairs and dealings with nature.
\end{abstract}

Keywords

Africa; spiritualism pragmatism science; neo-science

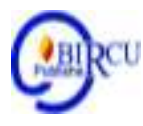

\section{Introduction}

This work locates the African philosophical system in spiritualism a doctrine recrudescent of pragmatism. Spiritualism is typical and topical all around traditional African cultures, empirically manifested in all areas of human knowledge and experience including its manifestations in medicine, communication and transportation, entertainment, and justice. An African machinative/spiritual capacity is a pragmatic reflection of African didactic strides towards untapped development; it makes possible the 'talking donkey just as the unpiloted drone-jet-plane, cell transplant, robotic and other artificial intelligences and animations; an African spiritual prudence is reductive/defiant of million distances apart to mere centimeters; and, in the least, it radically rebuts the authenticity of elasticity/elastic limit and is defies of the law of gravitation. While this categorization may be apt and adequate for those sympathetic with truth and the African course, it, however, is either untrue or a mark primitivism, unscientific, outmoded and untenable for others. Surprisingly, one of the foremost but critical views on this realistic depiction of African pragmatism is also an African, the Beninese Pauline Hountondji, born on 11th April, 1942 in Abidjan Cote D'Ivoire. In this work, the major substance of his views is here tersely represented and reviewed. Particularly, much interest would be cast on and critical of Hountondji's views to the extent such are contradicted by the favorable ones offered by the 
process philosophies of Henry Bergson and Alfred North Whitehead. The trajectory is to build a strong theoretical pedestal for the grounding of an African esoteric epistemology, which is at once uniquely spiritual and pragmatic; it is the imperative of this work, therefore, to espouse on the phrase we shall call pragmatic spiritualism.

\section{Review of Literatures}

\subsection{Spirits/Spiritualism}

A spirit is "The animating or vital principle in man (and animals) that gives life to the physical organism...the breath of life" [Oxford, vol. 10, p. 1]. From Anaxagoras that spirit is "the active principle of order in all things", through its Christian interpretation, to Leibniz and other critical ideas of it, the term has had rich history and changing interpretations; but its essential element remains: non-material forces in nature and beyond; a force that denotes the unity and interaction of all things. There are human and nature or ghost spirits. The idea of spirits may not be rotational but it is real and vivid in traditional African daily life. Truly, the African conceives of "Force" as being, that "Being is force" and the concept "Force" is inseparable from the definition of "Being"; thus there is no idea among the Africans of "Being" divorced from the idea of "Force". [Horton, 1974, pp. 146147], comparing African thought and Western science, tried to explain why explanations in modern Western culture tend to be couched in an impersonal idiom while explanations in traditional African society tend to be couched in a personal idiom. According to Ruch and Anyanwu [1981, p. 146], the "African world is one of participation between what Western philosophy considers as two distinct and partly separate worlds. The world which falls under our sense is not merely a shadow of the sacred transcendental world as it would be for Plato." Thus by spiritualism, we do not mean the doctrine that "spirit is the ultimate substance of the world', but the belief and effective actions denoting "that spirits of the dead communicate with the living, through whatever medium" (Blackburn, 1996, p. 361). More so, it shall be adapted to mean the philosophy depicting the totality of the beliefs and correlate activity, mostly surreptitious but indicative of metaphysical imputations or categories as sorcery, witchcraft, and magic. Thus spirit or spiritualism "refers to the condition of (man, nature, society) being affected by forces or entities that are normally invisible..." (Ogbenika, 2011, p. 55) and, although not unique to it, traditional African cultures are replete with these categories, whether or not such remain clandestine or become evidently manifest in their daily life/living and material reality [Levack, 1995, p. 42].

\subsection{Pragmatism}

The base of any tenable theory today is not the process but its pragmatic worth. By pragmatism,according to the Oxforddictionaryis meant 'thinking about solving problems in a practical and sensible way...' [Oxford, 2005, p. 1138]. Even though this definition points to the element of praxis, it does not stress that of the result as the thought itself. Hence Hogan sees pragmatism as the "philosophical theory of meaning, truth and value in which the empirically ascertainable consequences imply that an idea or statements are held to constitute the meaning of the statement and...the criterion for the truth of the statement" (Hogan, 2006, p. 281).This definition stresses as pragmatic the criterion, the process and the consequence of the idea. However, these definitions follow the formulations by both Peirce and James that the philosophy of meaning and truth that the meaning of a doctrine is the same as the practical effect of adopting it. For Peirce, it is a guide for judgment; and on 
his' and James's view, almost any belief might be respectable, and even true, provided it works" [Blackburn, 1996, p. 297]. Fortunately, the populist pragmatic theory and both Bergson's and Whiteheadian philosophies separately but consistently adulate aspects of spiritualism, thereby admittance of a place for an African spiritualism so denigrated by Paulin Hountondji.

\section{Research Methods}

The tools used in this research include hermeneutics which is the interpretation of text. Next is the interview of some philosophical sages in Auchi, Edo State. The aim of this method is to enable us understand the positions of the various scholars on African spiritualism. Interviewing elders will enable us understand African wisdom which is believe to be repository in elders.

\section{Discussion}

\subsection{Hountondji on African Philosophy}

In his seminal work, African philosophy, myth and reality, Hountondji, rejecting all other approaches in African philosophy, moves towards a synthesis of traditional African thought and rigorous philosophical method" [Oladipo, 1990, p. 60]. Hountondji is of the view that African philosophy is as a result of our philosophical literature and this is gotten from our past and he describes African philosophy as "...the set of text written by African and described as philosophical by their authors... as a body of literature whose existence is undeniable." Hountondji's main point of argument could be tersely put as follows that:

i. Philosophy is a set of text written by Africans and described as philosophical by their authors themselves (and also addressed to Africans);

ii. What is generally referred to as African philosophy is not essentially different from ethno-philosophy [Oladipo, 1997, p. 33].

iii.By proposing an African philosophy, we unwittingly play into the hands of colonialist and historians who insist that Africans are different from Europeans, and any reference to African philosophy forces us to define Africa with respect to Europe [Otakpor, 1990, 174].

iv. Philosophy in the strict sense of the word must be a scientific theoretical and individual discipline just like algebra, physics or linguistic and can therefore not be replaced by popular belief, traditional practices and a collective and conscious behavior.

$\mathrm{v}$. This creation of an African philosophy cannot be made ex-nihilo, that it comprises necessarily of a whole cultural heritage and consist mostly of the time of nothing but a re-creation.

Consequently, Hountondji calls for an adequate, proper incisive and painstaking evaluation of all that is so far taken as African philosophy which has it root in ethnography [13, Ruch and Anyanwu:12).Hountondji says:

Admit then, that our philosophy is yet to come take the word 'philosophy' in the active, not passive sense we do not need a closed system to which all of us can adhere and which we can all of us can adhere and which we can exhibit to the outside world. No we want the restless questioning, the untiring dialectic that accidentally produces systems and then projects them towards a horizon of fresh truth [Otakpor, 1990, p. 175].

Accordingly, in an attempt to formulate an idea of African philosophy different from 
Oruka's ethno-philosophy, he claimed that African philosophy does not grow out of myth, he defined philosophy as a "theory of science, a theory of nature and of the conditions under which a scientific discourse is possible" (Otakpor, 1990, p. 53) that philosophy is by its "historical constitution and essential nature, a second order of science in it empirical practice which will give rise to change" (Otakpor, 1990, p. 28). He intends African philosophy to be in relations to the western concept of philosophy which he described as universal philosophy, if it is science inclined, it must be a creation of individual activity, must aim towards the present and the future, should be opposed to mystical and dogmatic and conservative world view and should be objective, rational, factual, empirical and universal. He states that "Behind and beyond the ethnological pretext, philosophical view remains (Azenabor, 2002, p. 154). For him, there can no longer be any doubt about the existence of African philosophy... it exist as a particular form of scientific literature" (Huntondji, 2002, p. 63).

Though Hountondji was known for his critique of ethno-philosophy and endorsement of a critical, analytic and scientific understanding of philosophy, he suggested a critical evaluation of the relationship between philosophy, science and development, and also the need to re-examine the very foundations of the discipline. Acceptable are much of Hountondji's criticism of popular conception of African philosophy, especially his demand for an active philosophy. Hence he posits an African philosophy with some scientific semblance-which is the main focus of this work. Hountondji further introduced a methodology which revolves around the scientific orientation. For him, Africans should develop a scientific tradition in order to produce a philosophy; he further declares that

The development of philosophy is in some way a function of the

development of science we shall never have African philosophy in the

strict sense until we have produced in Africa a history of science"

(Owolabi, 1999, p. 66).

Various African philosophers have presented the method of how an African philosophy ought to be like, the question till remains, how do we know the method suitable for producing an authentic African philosophy? Wiredu advocates reconstruction, Bodunrin universal philosophy, for instance. Hountondji's scientific orientation in African philosophy seems to be a convincing method, not only did he suggest a scientific culture but is of the view that without a scientific culture there cannot be development in African and modern African urgently needs development. So for Hountondji, instead of claiming the existence of an African philosophy, we are advised to work toward achieving, what he calls "African Science". Hence he writes, "what African needs first is science and not philosophy" and he maintained that until we create a "a fruitful project of our philosophy" which is closely attached to the destiny of science" there cannot be an authentic African Philosophy. However, the senses in Hountodji's refutations have some points to contend with - the three senses of the word philosophy, the dictates of science, and the elements of pragmatism.

\subsection{Pragmatic Spiritualism/Spiritual Pragmatism}

It should be remembered here that "Before colonization, Africans had their own ways and methods of education. Its finality was to educate their children in accordance with African values." (Diakhaté, 2021, p. 1) this is as demonstrated in Achebe's Things Fall Apart. The idea of African spiritualism is also explicit noted by Achebe. Hence, it might be more congenial to begin with the concept of spiritualism; it, along with that of pragmatism, would enable us situate the province of spiritual pragmatism. The efficiency of spiritualism in Africa is congenial to Peirce's 'practical consequences'- to wit, that spiritual 
machinations do possess effective practical implication and bearing. According to Peirce, the aim, after all, "of pragmatic clarification is to rid metaphysics of un-clarity and make it possible to solve its problems" [Popkin, 1999, p. 595]. By the record of its efficiency in the areas of justice, art, communication, and medicine, for instance, African spiritualism also satisfies both Dewey's humanistic conception of practice and James's 'effects of a practical kind' which (though could be appropriated to harm) are altruistic in nature. Consequently, effective spiritualism in Africa shall henceforth be described as 'spiritual pragmatism', or more appropriately, 'pragmatic spiritualism'; its essence may seem to defy the laws of science, but not of general experience or of nature, as in the practice and effect of witchcraft, magic and sorcery, for instance. Such is the traditional African culture, and hence the UNESCO Declaration of 2001 holds that culture "should be regarded as the set of distinctive, spiritual, material, intellectual, and emotional features of society or a social group, and that it encompasses, in addition to art and literature, life-styles, ways of living together, value systems, traditions and beliefs." Africans places high emphasis and value on harmonious personal relationship. For instance, there is special respect shown to persons like the traditional healer/doctor and the rain-maker whose skills are considered as a mixture of 'scientific' and 'spiritual' powers/elements, and whose activities commit to restoring or maintaining good relations between their ancestors, gods, and their descendants, between man, nature, and spirits [Onyemelukwe, 1973, p. 26].

There exists other spiritual applicability. Witchcraft, magic and sorcery are an independent complex of beliefs and practices among mostly tribal /traditional societies. Witches and sorcerers mostly possess hostile motives and therefore engage in magical act to inflict mysterious misfortune on their victims. Witchcraft is a belief in an inherent, and often inherited, organic attribute of a person, with a power to harm (though not all witches harm) others with some unobservable means and at a distance. So a sorcerer is one who engages in "deliberate of evil magic to harm others. A magic is "the employment of substances, rites and spell to achieve aims by means not under sensory observation and control. Though this is not direct assault, it is motivated and animated by vicious and hostile feelings, jeered towards the control of the environment and social relations. It can be positively or negatively employed - even against witches and sorcerers - though without scientifically measurable effort or achievement [Mitchell, 1981, p. 46]. Consequently, many (free) individuals try not to associate with witches by tying of charms around the waist of both children and adults is said to scare away witches/wizards from such people or by seeking the protection of gods/goddesses of the land, while the Christians go to their various Churches to commit their lives to God, and while the Muslims do just the same in their mosque (Aigbona, 2015).

Let it be stated that an understanding of science informs that products take precedence over thought; yet products are consequences of thought. How then should the product of thought count as being scientific yet, the thought, its base does not? Any empirical product is thought objectivized. Take introspection, for instance. Introspection, like spiritualism, is internal perception; perception implies material entities. Thus introspection implies that perceiving ideas in the mind are material entities. In this way, introspection is a science of some sort, a subjective objectivity because making report of one's mental life is itself a piece of behavior-which can be studied objectively as any other. Similarly is intuition, which in Kant has an empirical form and structures sensation into the experience of things in space and time; or could mathematics (which is the mental constructions of mathematicians) be rather scientific? And the power of precognition (the ability to foresee events both before they happen and before there is normal evidence that they are going to happen) validates introspection and intuitionism. 


\subsection{Refuting Hountondji's Perception of African Philosophy}

Now we turn to a more general refutation of Hountondji's requirement for an African philosophy. The first issue is tied to Hountondji's restriction of the term, philosophy to just critical activity. However, besides his, there are other two senses of the word philosophy. The first is that the term is of Greek origination (an abridgement of philo and sophia which translates to the love of wisdom). Most generally, the term also denotes the totality of a person's (or people's) worldview-including beliefs, epistemology, socio-politics, and methods of law, morality and justice amid other ways of doing. While one need not border on the second (concerning origins of term), it remains undisputable that as long as Africans, singly or socially, have a perception of reality, then is African philosophy. Hence Mbiti says African philosophy "refers to the understanding, attitude of mind, logic and perception behind the manner in which Africans think, act or speak in different situations of life" and it is extracted from proverbs, and morals of oral tradition of each African community [Mbiti, 1982, p. 2]. Invariably, this is a traditional construal of philosophy by relying on myths and beliefs; in this respect, it is not evaluative. In this way, African cultures inform African philosophy, as against Hountondji's position.

Similarly, Hountondji does not consider the broad nature of science. Ordinarily, science is a method of inquiry which thrives on observation and stresses experimentation. In this way, science is predicated on materialism/physicalism and experience. In some respect, science refers to any "body of systematized knowledge..." [Aigbodioh, 1997, p. 1). Or, as Morgan [Morgan 1979, p. xviii) says, science is "any activity resulting in knowledge and understanding about the world.'Does African spiritualism not make this requirement?

The philosophies of Bergson and Whitehead, often called process philosophers, also offer a strong opportunity to reject Hountondji's. A Polish born in Paris in 1859, one of the most famous and influential French philosophers of the late 19th century to early 20th century, Bergson wrote a series of works that won wide attention and stimulated considerable discussion, including Time and Free Will (1889), Matter and Memory (1897), An Introduction to Metaphysics (1903), Creative Evolution (1907) and The Two Sources of Morality and Religion (1932) — of which the last three gained particular fame and contain his most distinctive ideas before his death in 1941 at the age of 82 (Stumpf, 2008, p. 409). Alfred North Whitehead was born February 1861 in Kent, England, and the coauthor of Principia Mathematica (1910 - 1913). He died in 1947.

Both Whitehead and Bergson's philosophy are described as 'process philosophy' for they believe in change in the philosophical system, they were against the stream of the history of philosophy by emphasizing a process view over a substance view, they stood out among their contemporaries in trying to make a speculative form of metaphysic, they also tried to reconcile the diverse intuition found in the human experience into a coherent holistic scheme and reconcile intuition of objective and subjective views. Consider Bergson's creative evolution' for instance, stresses creative or vital force. Against Darwin, evolution, said Bergson is best explained in terms of a vital impulse which is the essential interior element of all living beings and is the creative power that moves in unbroken continuity through all things. Knowing for Bergson, is a secondary activity; more basic and therefore primarily is living. All things are motivated by this vital force which is the fundamental reality. One discovers it first through the immediate awareness of his own continuous self: discover that he endures. Traditional African ontology prioritizes the place of (vital) forces which Hountondji denounces. On this Bergson's philosophy of intuition(knowing or knowledge) is his conviction that there are 'two profoundly different way of knowing thing'. The first way he says, is 'that we move around the object' (which 
leads to subjective truth), and the second 'that we enter into it' (which considers essences, which themselves are not material objects of sensual experience). Entering-into is essentially metaphysical, which is the African reality. The second kind of knowledge is absolute says Bergson because in this case by entering the object we overcome the limitation of any particular perspective and grasps the object as it really is" [Stumpf, 2008, p. 409].

On his part, Whitehead's theory of prehension stipulates that" we do not ever experience a single isolated actual entity but only aggregate of the entities" [Williams, 2006 , p. 484]. He calls an aggregate of actual entities either a society or a nexus (plural nexus) in which the entities are united by their prehension. Creativity is the fundamental characteristic of the process of nature. Creativity, for Whitehead, is the ultimate principle by which the many enter into complex unity. If we take each actual entity separately, we should have a disjointed universe, but the creative unity of the many, constitutes the conjoined universe. Following Whitehead, Hountondji's could best be considered racist, inauthentic and suppressive of African reality; the attitude could generate inauthentic existence and bad faith for his sympathizers and the innocent alike. His, like other adulations of science, "...was built on a questionable physical outlook called science materialism" leading to the "fallacy of misplaced concreteness" [Hountondji, p. 25]. Following from the process philosophers who agree to the fact that "metaphysic studies reality and the basic unity of reality" and also Hountondji's opposing of a mystical, dogmatic and conservative worldview" which have seen as invalid. Philosophy may be universal in nature; there are different approaches to it. And following Bergsonian and Whiteheadian theories of a speculative metaphysics, then we can convincingly say that there actually exists an African philosophy, a philosophy whose essence is spiritual primacy.

\section{Conclusion}

This work, at once, by stipulating the basic indices for a philosophy to count as scientific or pragmatic, fulfils Hountondji's demand for an African philosophy with a scientific outlook; and is a rejection of Hountondji's denouncement of an African philosophy for it has been shown that the practical effect/worth of the practice of spiritualism in Africa has vindicated its philosophy as not only scientific but also pragmatic. The import of this status is the fact that what counts as scientific does not rely on method/process but also on outcome/result — again, as demonstrated in Bergson's and Whitehead's process philosophies. What perhaps could have been the merit in Hountondji's worries is that African spiritualism should be brought to bear on resolving the various infamies confronting the African world. This work has demonstrated this capacity. While existentialism rules western philosophy, essentialism pervades all of traditional African thought; hence issues about life, hunger, war, birth, death, suffering, freedom, fear, injustice, tragedy, etc. do not arise. However, those issues are considered only after and in so far they are subsumed within the gamut of essentialism. In other words, issues are not so considered or worrisome among the traditional Africans because they remain open expressions or manifestations of some other platform-metaphysical in nature. If philosophical cognition is considered pre-science cognition, then African spiritualism is surely a neo- or post-scientific cognition in acting out of its own inner nature [Blackburn, 1986, p. 282] - the perspectivization of both capacities ought to be essence of modern scientology. 
In a cryptic consideration, the world of justice, causality, transport/telecommunication, medicine, efficacious spiritualism system/mode possesses some perseity. For us in Africa, such, definitely is the future in our past which, perhaps, Hountondji does not recognize. Fortunately, the efficiency of spiritual pragmatism is congenial to Peirce's 'practical consequences' to wit, that spiritual machinations do possess effective practical implication and bearing. According to Piece, the aim, after all, "of pragmatic clarification is to rid metaphysics of un-clarity and make it possible to solve its problems" [Popkin, $p$. 595]. By the record of its efficiency in the areas of justice, art, communication, and medicine, for instance, pragmatic spiritualism also satisfies both Dewey's humanistic conception of practice and James's 'effects of a practical kind' which (though could be appropriated to harm) are altruistic in nature. Spiritual pragmatism, or more appropriately, pragmatic spiritualism, may seem to defy the laws of science, but not of general experience or of nature.

Accordingly, a rejection of African pragmatic spiritualism as objective amounts to a denial/condemnation of Peirce's principle - of pragmatic consequences; it touts as senseless the 'talking donkey', and denies the reality of a 'Drone-jet-plane'; it rejects cell transplant, robotic and other artificial intelligences/animations. African spiritual prudence is defiant of distances but brings to close proximity places set apart by a million mile to mere meters; it all radically rebuts the authenticity of elasticity/elastic limit and defies the law of gravitation. Hence, craft, that African craft is not only a boundless and costless carrier; it is a potential rational/spiritual scanner (organically and mechanically); a mentaldetector, a health machine, a geographical chronometer, a nuclear energy/force, and... Just imagine a world without wires but waves, where waves/hurricane are controlled and redirected; imagine a world without courts but judgments, one without drugs but healings, one without laws but responsibility and order. Think of a world without guns/bombs but guided missiles where there are no institutions but there is learning [Asekhauno and Inagbor, 2011, pp. 239-249]. A world without illness and diseases would need no herbal tea like moringa leaves. Perhaps, all we would need cleanliness because "Cleanliness is very important because of the increasing number of diseases that arise due to bacteria and germs" (Nasution, 2021, pp. 1705-1712) imagine a world without aircrafts but flights, without clouds but rains, and without the sun but light. And yet imagine a world without dams/generators but power. The possibilities are in-exhaustive. But be encouraged to imagine, beyond the feat of fuel-powered automobile and airplane (which pollutes nature) to electrically/spiritual propelled machines (ensuring such don't blow-up the world); beyond social media replete with dangerous radio-active material to non-radioactive sources; just imagine such a world, realizable not just through the extant energy-sapping scientific procedures but by some (African) pragmatic spiritualism-which is the neoscience.

On a final note, it must be remarked that human existence is a dynamic process involving the increase or decrease of power or life force, of living or dying. Tempels describes every misfortune that Africa encounters as 'diminution of vital force' [Tempels, 1959, p. 33]. Illness and death may result from some outside agent, a person, thing, or circumstances that weakens people because the agent contains a greater life force. Hence words may be the vehicle for the application of this vital force. Although the efficacy and usages of these words has been altered and almost oblique by the widespread influence of Christianity, Islam, and modernity and thus some of spiritual uses of words disappearing, such role still obtains. As long as there is an African metaphysics, words will still be vehicle for communication between various levels or hierarchy of forces. Just as African Traditional Religion (ATR) requires a liturgy and theology, African philosophy does 
require a philosophy, its philosophical system. The challenge now is for us to exhume, revivify, refine, and appropriate those powers to suit contemporary challenges in the physical world for national and international development; such could even be one of our contributions at globalization.

\section{References}

Aigbodioh, J. A. (1997)Philosophy of Science. Ibadan: Hope Publications.

Aigbona, I. (2015) Trado-medical healer. Personal Interview. Elele-Uzairue, August 16.

Asekhauno, A. A. and Inagbor, V. A. (2011) "Magic, witcheraft and sorcery in warfare: The experience of the Etsako of Nigeria."MATATU: Journal for African Culture and Society, 40: 239-249.

Azenabor, G. (2002). Understanding the problems on African philosophy.Lagos: First Academic publishers.

Bodunrin, P. O. (1991). "The question of African Philosophy." In: Tsenary Sereheberhan, (ed.) African Philosophy; The Essential Readings. London: Clarendon Press, 63-86.

Diakhaté, B. (2021). "Traditional Education: Methods and Finality in Chinua Achebe's Things Fall Apart (1958) and Arrow of God (1969)" Budapest International Research and Critics in Linguistics and Education (BirLE) Journal Volume 4, No 1, February, 2021, pp. 1-6

Hogan, M. O. (2006). Dictionary of Sociology, New Delhi, Academic Publishers.

Hountondji, P. (1981). Philosophical trends in Contemporary Africa. Rome: offficiumlibricatholici.

Hountondji, P. (1997). African philosophy: Myth and Reality, Indianapolis: Indiana University Press.

Hountondji, P. (1976). "La Sens du mot Philosophiedans, L'expressionPhilosophieAfriacaine, Ron zoed."Paper given at a Seminar on African Philosophy, held at Addis Ababa, 1-3 December, 1976.

Hountondji, P. (2002). The Struggle for Meaning: Reflections on Philosophy, Culture and Democracy in Africa, Athens: Ohio University Press, 2002.

Horton, R. (1974). "African thought and Western science in rationality." In: Wilson, B. R. (ed.), Rationality, Oxford: Basil Blackwell, 1974: 146-147.

Levack, B. (1995). The Witch-Hunt in Early Modern Europe, 2nd ed. London: Longman Group Limited.

Mbiti, J. S. (1982). African Religions and Philosophy. London: Heinemann Educational Books.

Mitchell, G. D. (1981). A New Dictionary of Sociology. London: Routledge \& Kegan Paul.

Morgan, Robert P. et al. (1979). Science and Technology for development: The Role of US Unversities. New York: Pergamon Press.

Murray, N. (1925). Witchcraft cult in Western Europe: A study in anthropology. London: LGL.

Nasution, A. N. (2021). "Enhance Effectiveness of Moringa Leaves with Staphylococcus Epidermidis Bacteria" Budapest International Research and Critics Institute-Journal (BIRCI-Journal)Volume 4, No. 2, May, 2021, pp. 1705-1712

Ogbenika, G.E. (2011). The Idea of Spirit in African Philosophy. Ibadan: Safmos Publishers.

Oladipo, O. (1990). "Metaphysics, religion, and Yoruba traditional thought."Indian journal of philosophical research VII. 2, (Jan.-April, 1990): 63-80. 
Onyemelukwe, C. C. (1973). Men and Management in Contemporary Africa. London: Longman Group Ltd.

Oruka, O. H.( 1975). Trends in Contemporary African Philosophy. Nairobi: Sherikon.

Otakpor, N. (1990). "African philosophy Paulin J. Hontondji-His Dilemma and Contributions.”Indian Philosophical Quarterly, xvii. 2, 165-171.

Owolabi, K. A. (1999). "Orientation in African philosophy: A critical survey."Indian Philosophical Quarterly, xxvi. 1, 211-221.

Oxford Advanced Learner's Dictionary, 7th Edition, Oxford: OUP, 2005.

Popkin, R. H. (Ed.) (1999). The Columbia History of Western Philosophy. New York: Columbia University Press.

Ruch, E. A. \& Anyanwu, K.C. (1981). African philosophy: An Introduction to the main philosophical Trends in Contemporary Africa. Rome: Catholic Book Agency.

Pulling, P. and Cawthon, K. (1989). The Devil id Web. Louisianan: Huntington House.

Stumpf, S.E and Fiesser, J. (2008). Socrates to Sartre and Beyond: A History of Philosophy. New York: McGraw Hill.

Tempels, P.Bantu Philosophy.Paris: Presence Africaine, 1959.

The Oxford English Dictionary.

Lawhead, W.F. (2006). The Voyage of Discovery; A Historical Introduction to Philosophy. Cengage Learning. 